\title{
Korelasi Skala FLACC dengan Kadar Alfa Amilase Saliva pada Anak Palsi Serebral
}

Rissa Puspitari Sabur, Nelly Amalia Risan, Alex Chairulfatah

Departemen Ilmu Kesehatan Anak Fakultas Kedokteran Universitas Padjadjaran/Rumah Sakit dr. Hasan Sadikin Bandung

Latar belakang. Skala face, leg, activities, cry, and consolability (FLACC) diketahui dapat menilai nyeri pada anak palsi serebral (PS). Alfa amilase saliva (AAS) yang diambil dari saliva juga meningkat pada anak palsi serebral yang dilakukan tindakan invasif pengambilan darah vena. Korelasi antara kedua jenis pemeriksaan ini belum diketahui.

Tujuan. Menentukan korelasi skor FLACC dengan kadar AAS pada anak PS.

Metode. Penelitian analitik observasional dengan rancangan potong lintang, yaitu mengukur derajat nyeri menggunakan skala FLACC dengan mengamati perilaku subjek dan menilai perilaku sesuai yang tertera pada formulir FLACC. Kadar AAS diperiksa sebelum dilakukan tindakan fisioterapi. Pengukuran kadar AAS dengan metode spektrofotometri pada anak yang telah didiagnosis PS yang datang berobat di Poliklinik Neurologi Anak dan Unit Rehabilitasi Medik Rumah Sakit Hasan Sadikin Bandung, berusia 6 bulan-14 tahun, periode Januari - Maret 2016. Analisis data digunakan uji korelasi Rank Spearman dengan kemaknaan $\mathrm{p}<0,05$. Hasil. Didapat 42 pasien anak dengan diagnosis PS. Uji statistik menggunakan uji korelasi Rank Spearman menunjukkan terdapat korelasi yang lemah antara skor FLACC dan kadar AAS ( $\mathrm{r}=0,364 ; p=0,034)$ pada kelompok usia $>24$ bulan.

Kesimpulan. Peningkatan skor FLACC kecenderungan diikuti dengan peningkatan kadar AAS pada anak PS. Sari Pediatri 2016;18(2):142-5

Kata kunci: kadar alfa amilase saliva, skala FLACC, palsi serebral, derajat fungsional motorik, gross motor function classification system

\section{Correlation between FLACC Score and SAA Level of Pediatric CP Patients}

Rissa Puspitari Sabur, Nelly Amalia Risan, Alex Chairulfatah

Background.Children with cerebral palsy (CP) often experience pain and can be assessed by Face, Leg, Activities, Cry, and Consolability (FLACC) scale and salivary alpha-amylase (sAA) level as a new, objective, noninvasive biomarker to assess pain in children with CP. Objective. This study was to determine correlation between FLACC score and SAA level of pediatric CP patients.

Methods. This was a cross sectional, analytical observational study to determine pain level using FLACC score and SAA level in pediatric patients aged 6 months-14 years diagnosed with CP in Pediatric Neurology Clinic Dr. Hasan Sadikin Hospital, Bandung from January to March 2016.

Results. Data analysis by Rank Spearman method revealed weak correlation between pain level based on FLACC score and SAA level $(\mathrm{r}=0.364, \mathrm{p}=0.034)$ in children $>24$ months old.

Conclusion. Increasing FLACC score would be followed by increasing SAA level. Sari Pediatri 2016;18(2):142-5

Keywords: Salivary alpha amylase, FLACC scale, cerebral palsy, gross motor function classification system.

Alamat korespondensi: Dr. Rissa Puspitari Sabur. Departemen Ilmu Kesehatan Anak Fakultas Kedokteran Universitas Padjadjaran/Rumah Sakit dr. Hasan Sadikin, Bandung. E-mail: rissapuspitarisabur@yahoo.co.id 
B eberapa penelitian di luar negeri, prevalensi palsi serebral (PS) dilaporkan bervariasi 1,52,5 kasus dari tiap 1000 kelahiran hidup. ${ }^{1}$ Di Indonesia, insiden PS belum diketahui. Pasien PS sering kali memiliki masalah neurologis, seperti epilepsi, disabilitas intelektual, cortical visual impairment, dan retinopati, serta tuli sensorineural. ${ }^{2,3}$ Gangguan motorik merupakan masalah utama pasien PS dan salah satu gejalanya adalah nyeri akibat spastisitas, kontraktur, distonia, subluksasi, dislokasi serta kelainan postur, dan prosedur pemeriksaan maupun fisioterapi. ${ }^{4}$ Anak PS memiliki keterbatasan dalam mengekspresikan rasa nyeri. ${ }^{5}$ Nyeri tersebut dapat diperiksa dengan skala nyeri face, legs, activity, cry, and consolability (FLACC). ${ }^{6}$ Skala nyeri FLACC digunakan untuk menilai nyeri dengan sah dan dapat dipercaya pada anak dengan gangguan kognitif.,

Kadar AAS yang diambil dari saliva diketahui merupakan salah satu indikator dari suatu stres akibat nyeri. ${ }^{8}$ Kadar alfa amilase saliva (AAS) dipengaruhi oleh usia di bawah 2 tahun. ${ }^{9}$ Kadar AAS normal adalah 4,1-423,1 IU/mL, sedangkan kadar AAS meningkat, yaitu $>423,1 \mathrm{IU} / \mathrm{mL}$. Diperlukan penelitian untuk menilai hubungan antara kadar AAS dan skala FLACC pada anak PS. Nyeri yang dirasakan anak PS diduga meningkatkan kadar AAS. Penelitian AAS pada anak PS belum dilakukan di Indonesia sehingga belum pernah dilaporkan maka peneliti ingin mengetahui hubungan antara skala FLACC dan kadar AAS.

\section{Metode}

Subjek penelitian adalah pasien dengan diagnosis PS yang datang berobat di Poliklinik Neurologi Anak dan Unit Rehabilitasi Medik Rumah Sakit Hasan Dr. Sadikin Bandung, berusia 6 bulan-14 tahun dan telah mendapat persetujuan tertulis dari orangtua/wali setelah diberi penjelasan untuk ikut dalam penelitian. Penelitian dilakukan di Poliklinik Neurologi Anak dan Unit Rehabilitasi Medik Rumah Sakit Dr. Hasan Sadikin Bandung. Penelitian selama Januari - Maret 2016.

Penelitian analitik observasional dengan rancangan cross sectional, yaitu mengukur derajat nyeri menggunakan skala FLACC dengan mengamati perilaku subjek dan menilai perilaku sesuai yang tertera pada formulir FLACC. Kadar AAS diperiksa sebelum dilakukan tindakan fisioterapi. Pengukuran kadar AAS dengan metode spektrofotometri. Aktivitas alfa amilase terlihat sesuai absorbansi yang terbaca pada gelombang $405 \mathrm{~nm}$. Dengan mengacu pada penelitian Shirasaki $\mathrm{dkk}^{10}$ diperoleh nilai $\mathrm{r}=0,561$ dan dengan memilih taraf kepercayaan $95 \%\left(Z_{\alpha}=1,96\right)$ dan power test $95 \%$ $\left(Z_{\beta}=1,65\right)$ dari tabel distribusi normal maka jumlah sampel minimal yang diperlukan adalah 37 orang.

$$
\mathrm{n}=+3
$$

Data dicatat jenis kelamin, usia, derajat PS, dan status gizi. Usia dibagi menjadi dua kelompok, yaitu 6-24 bulan dan $>24$ bulan. Data skor FLACC dikonversi menjadi numerik sebelum diolah. Analisis data yang digunakan untuk melihat korelasi data dengan sebaran tidak normal adalah uji korelasi Rank Spearman. Kekuatan korelasi ditentukan berdasarkan buku statistik untuk kedokteran dan kesehatan. ${ }^{11}$ Kemaknaan ditentukan berdasarkan nilai $\mathrm{p}<0,05$. Data yang terkumpul ditabulasi dan diolah secara statistik dengan menggunakan program SPSS 23.

\section{Hasil}

Selama periode penelitian didapat 42 pasien anak yang memenuhi kriteria inklusi, yaitu pasien PS berusia 6 bulan-14 tahun. Karakteristik subjek penelitian tertera pada Tabel 1, terdiri atas jenis kelamin, derajat fungsional motorik PS, dan status gizi. Subjek penelitian lebih banyak perempuan daripada lakilaki, derajat fungsional PS lebih banyak derajat berat daripada ringan-sedang, dan status gizi lebih banyak normal daripada malnutrisi sedang, berat, maupun overweight. Skor FLACC yang didapat nyaman-nyeri ringan lebih banyak daripada nyeri berat, sedangkan kadar AAS normal lebih banyak daripada kadar AAS meningkat.

Korelasi skor FLACC dengan kadar AAS berdasarkan kelompok usia tertera pada Tabel 2 .

\section{Pembahasan}

Penelitian kami menunjukkan bahwa terdapat korelasi lemah antara skor FLACC dan kadar AAS pada kelompok usia $>24$ bulan. Terdapat kecenderungan semakin tinggi skor FLACC, semakin tinggi pula 
Rissa Puspitari Sabur dkk.: Korelasi FLACC dengan Kadar AAS pada anak PS

Tabel 1. Karakteristik umum subjek penelitian

\begin{tabular}{lcccc}
\hline Karakteristik & Jumlah $(\mathrm{N}=42)$ & $\%$ & Rerata (simpang baku) & Median (rentang) \\
\hline Jenis kelamin & & & & \\
$\quad$ Laki-laki & 18 & 43 & & \\
$\quad$ Perempuan & 24 & 57 & & \\
Derajat fungsional motorik PS (GMFCS) & & & & \\
$\quad$ Ringan-sedang (I, II, III) & 13 & 31 & & \\
$\quad$ Berat (IV, V) & 29 & 69 & & \\
Status gizi & & & & \\
$\quad$ Normal & 32 & 76,2 & \\
$\quad$ Malnutrisi sedang & 5 & 11,9 & \\
$\quad$ Malnutrisi berat & 4 & 9,5 & \\
$\quad$ Overweight & 1 & 2,4 & & \\
FLACC & & & & \\
$\quad$ Nyaman/nyeri ringan (0-3) & 25 & 59,5 & & \\
$\quad$ Nyeri sedang-berat (4-10) & 17 & 40,5 & & \\
Kadar AAS (IU/mL) & & & & \\
$\quad$ Normal $(<423,1)$ & 33 & 78,6 & $243,61(207,95)$ & \\
$\quad$ Meningkat $(>423,1)$ & 9 & 21,4 & & \\
&
\end{tabular}

Tabel 2. Korelasi skor FLACC dengan kadar AAS berdasarkan kelompok usia

\begin{tabular}{lcc}
\hline \multirow{2}{*}{ Kelompok usia (bulan) } & \multicolumn{2}{c}{ Korelasi skor FLACC dengan kadar AAS* } \\
\cline { 2 - 3 } & $\mathrm{r}$ & Nilai $\mathrm{p}^{*}$ \\
\hline $6-24$ & $-0,329$ & 0,107 \\
$>24$ & 0,364 & 0,034 \\
\hline
\end{tabular}

${ }^{*}$ koefisien korelasi Rank Spearman,dengan kemaknaan $p<0,05$

kadar AAS meskipun dengan kekuatan korelasi lemah. Hal tersebut mungkin terjadi karena otak mengalami pertumbuhan dan perkembangan yang pesat pada 24 bulan pertama sehingga terdapat maturitas otak dan fungsi autonom yang lebih baik pada kelompok usia $>24$ bulan. ${ }^{12}$

Neurogenesis dimulai pada saat janin berusia trimester pertama dan lebih banyak terjadi pada saat prenatal. Setelah lahir, sinaptogenesis dan mielinisasi masih berlangsung dengan pesat sampai usia 24 bulan, setelah itu mengalami penurunan. ${ }^{13}$ Pengaturan kortikal batang otak meningkat selama tahun pertama. ${ }^{14}$ Bersamaan dengan perkembangan tersebut ketergantungan bayi terhadap ibunya akan berkurang, dan interaksi sosial akan meningkat. Anak akan memiliki respons yang lebih besar terhadap interaksi dengan lingkungannya termasuk terhadap rangsangan nyeri. ${ }^{14}$ Semakin matur sistem saraf maka semakin baik pula reaktivitas sistem saraf autonom terhadap stres berupa nyeri sehingga terjadi stimulasi simpatis, yaitu betaadrenergik dan peningkatan sekresi protein saliva termasuk AAS. ${ }^{14,15}$ Rangkaian peristiwa ini menjelaskan bahwa kadar AAS lebih tinggi pada anak usia $>24$ bulan daripada anak $\leq 24$ bulan karena proses maturitas otak termasuk sistem saraf simpatis pada usia $>24$ bulan yang lebih baik sehingga korelasi antara stres fisik berupa nyeri dan saraf autonom yang dinilai menggunakan skala FLACC dan kadar AAS baru terlihat setelah usia tersebut.

Anak yang lebih tua banyak mengalami spastisitas dan gejala yang terkait dengannya, seperti nyeri atau spasme otot, kelainan postur dan keterbatasan mobilitas. Anak-anak tersebut termasuk dalam GMFCS derajat 4 atau $5 .{ }^{16}$ Sejalan dengan penelitian tersebut, telah diteliti pula bahwa pada anak yang berusia lebih tua terdapat kontraktur, kekakuan otot, dan juga ketidaksejajaran 
tulang belakang, serta bertambahnya ukuran tubuh dan ketidakseimbangan postur yang menyebabkan nyeri pada anak PS berusia lebih tua. ${ }^{17}$ Skala FLACC masih dapat digunakan untuk anak meskipun bersifat subjektif. Kadar AAS belum dapat dipercaya digunakan untuk anak $<24$ bulan.

Keterbatasan penelitian kami yaitu hasil pemeriksaan FLACC yang bersifat subjektif sehingga dapat berbeda antara pemeriksa satu dan yang lain. Namun demikian, tenaga kesehatan yang membantu penelitian kami telah terlatih dan terampil menggunakan skala nyeri FLACC.

\section{Kesimpulan}

Peningkatan skor FLACC kecenderungan akan diikuti oleh peningkatan kadar AAS pada anak PS berusia lebih dari 24 bulan.

\section{Daftar pustaka}

1. Winter S, Autry A, Boyle C, Yeargin-Allsopp M. Trends in the prevalence of cerebral palsy in a population-based study. Pediatrics 2002;110:1220-7.

2. Jan M. Cerebral palsy: comprehensive review and update. Ann Saudi Med 2006;26:123-32.

3. Sankar C, Mundkur N. Cerebral palsy-definition, classification, etiology and early diagnosis. Indian J Pediatr 2005;72:865-8.

4. Penner M, Xie WY, Binepal N, Switzer L, Fehlings D. Characteristics of pain in children and youth with cerebral palsy. Pediatrics 2013;132:407-15.

5. Parkinson K, Gibson L, Dickinson H, Colver A. Pain in children with cerebral palsy: a cross-sectional multicentre European study. Acta Pædiatrica 2010;99:446-51.

6. Malviya S, Voepel-Lewis T, Merkel S, Tait AR. The revised
FLACC observational pain tool: improved reliability and validity for pain assessment in children with cognitive impairment. Ped Anesth 2006;16:258-65.

7. Merkel S, Voepel-Lewis T, Shayevitz J, Malviya S. The FLACC: a behavioral scale for scoring postoperative pain in young children. Pediatr Nurs 1997;23:293-7.

8. Nater U, Rohleder N. Salivary alpha-amylase as a non-invasive biomarker for the sympathetic nervous system: current state of research. Psychoneuroendocrinology 2009;34:486-96.

9. Salimetrics. Salivary $\alpha$-amylase assay kit. Salivary $\alpha$-Amylase Assay Kit Insert 2012;1-1902-5.

10. Shirasaki S, Fujii H, Takahashi M, Sato T, Ebina M, Noto Y, $\mathrm{dkkl}$. Correlation between salivary-amylase activity and pain scale in patients with chronic pain. Reg Anesth Pain Med 2007;32:120-3.

11. Dahlan MS. Statistik untuk kedokteran dan kesehatan. Edisi ke-6. Jakarta: Epidemiologi Indonesia; 2014.

12. Stiles J, Jernigan TL. The basics of brain development. Neuropsychol Rev 2010;20:327-48.

13. Mundkur N. Neuroplasticity in children. Indian J Pediatr 2005;72:1-3.

14. Porges SW, Furman SA. The early development of the autonomic nervous system provides a neural platform for social behavior: a polyvagal perspective. Infant Child Dev 2011;20:106-18.

15. Alkon A, Boyce WT, Davis NV, Eskenazi B. Developmental changes in autonomic nervous system resting and reactivity measures in latino children from 6 to 60 months of age. J Dev Behav Pediatr 2011;32:668-77.

16. Eunson P, Allan G, Barnes L, Carr L, Cawker S, Dixon E, dkk. Spasticity in children and young people with non-progressive brain disorders: management of spasticity and co-existing motor disorders and their early musculoskeletal complications NICE guideline. NICE 2011:30-5.

17. Hanna SE, Rosenbaum PL, Bartlett DJ, Palisano RJ, Walter $\mathrm{SD}$, Avery L, dkk. Stability and decline in gross motor function among children and youth with cerebral palsy aged 2 to 21 years. Develop Med Child Neurol 2009:1-9. 